\title{
Effects of a long term water level reduction on the ecology and water quality in an eastern Mediterranean lake
}

\author{
K. Stefanidis ${ }^{(1)}$, E. Papastergiadou ${ }^{(1), \star}$
}

Received February 5, 2013

Revised August 1, 2013

Accepted August 2, 2013

Key-words:

fish,

macrophytes, water level

fluctuation, water quality, zooplankton

\section{ABSTRACT}

Water level fluctuations play a significant role in the lake nutrient dynamics, and consequently may have a strong influence on the biological communities and productivity. In this article we investigated the effects of a long term water level reduction on key chemistry parameters and major biological communities in an eastern Mediterranean lake. Our approach is based on temporal data regarding water quality, fish, zooplankton and aquatic vegetation that are representative of different water level periods. The results revealed significant correlations between water level, conductivity and chloride concentration suggesting a clear effect of the water level reduction on the water quality. Among the key findings of this study is the significant increase of zoobenthivorous fish (roach and carp) from 1973 to 1999 that correlates with the water level reduction. A decline of charophytes is also noted whereas the reed beds appear to have expanded at the shallower parts of the lake. The zooplankton composition of the lake is mostly dominated by nauplii, rotifer and small-sized crustaceans indicating a possible effect of fish predation. Overall, this article has ascertained an alarming shift of water quality and composition of biological communities that can be attributed to the combined effects of eutrophication and the extreme water level decrease.

RÉSUMÉ

Effets d'une réduction du niveau d'eau à long terme sur la qualité de l'écologie et de l'eau dans un lac en Méditerranée orientale

Mots-clés : fluctuations du niveau d'eau, macrophytes, pêche, qualité de l'eau, zooplancton
Les variations du niveau d'eau jouent un rôle important dans la dynamique des nutriments d'un lac, et par conséquent peuvent avoir une forte influence sur les communautés biologiques et la productivité. Dans cet article, nous avons étudié les effets d'une réduction à long terme des niveaux d'eau sur les paramètres chimiques et les principales communautés biologiques dans un lac en Méditerranée orientale. Notre approche est basée sur des données temporelles relatives à la qualité de l'eau, les poissons, le zooplancton et la végétation aquatique qui sont représentatives des différentes périodes de niveau d'eau. Les résultats ont révélé des corrélations significatives entre le niveau de l'eau, la conductivité et la concentration de chlorure suggérant un effet évident de la réduction du niveau d'eau sur la qualité de l'eau. Parmi les principales conclusions de cette étude, on note l'augmentation significative des poissons zoobenthivores (gardons et carpes) de 1973 à 1999 qui est en corrélation avec la réduction du niveau d'eau. Une baisse des

(1) Department of Biology, University of Patras GR 26500, Patras Greece

* Corresponding author: evapap@upatras.gr 
charophytes est également notée alors que les roselières se sont élargies dans les parties peu profondes du lac. La composition du zooplancton du lac est principalement dominée par les nauplii, rotifères et crustacés de petite taille indiquant un possible effet de la prédation des poissons. Dans l'ensemble, cette étude a constaté une évolution alarmante de la qualité de l'eau et de la composition des communautés biologiques qui peuvent être attribuées aux effets combinés de l'eutrophisation et de la baisse importante du niveau d'eau.

\section{INTRODUCTION}

Lake ecosystems are particularly sensitive to a number of anthropogenic stressors. Apart from the nutrient inputs and the eutrophication problems, hydrological alterations emerge as another major threat to the ecology of lakes and littoral communities. Water level fluctuations (WLFs) are known to play a key role in a lake's physical processes but also have a crucial effect on the ecology of the biota that live in the littoral zone (Coops et al., 2003). Specifically, in the Mediterranean region the WLFs may have a drastic effect on the ecology of freshwater lakes including effects on the dynamics and structure of the biotic communities, increase of turbidity and a shift to brackish or even saline conditions (Beklioglu et al., 2006). The pattern of WLF may determine the extent of the littoral zone and the depth distribution of the aquatic macrophytes. Especially, in shallow lakes, annual WLFs can influence the extent and the structure of the littoral and the aquatic terrestrial transitional zone in a positive manner by creating greater habitat diversity (Coops et al., 2003). Hydrological changes may also affect the structure of plankton and fish communities. Even small changes in the salinity levels combined with an increase of submerged vegetation can offer an opportunity to salinity tolerant copepods and plant associated rotifers to dominate during the low water level periods (Romo et al., 2004). Consequently, the changes in the coverage of the submerged vegetation are likely to have a striking effect on the spawning ground and foraging habitat of littoral fish communities. Therefore WLFs may alter the fish spawning success and the role of fish predation on the zooplankton, ultimately affecting the top-down control mechanisms and the trophic interactions between the aquatic communities. Although in deep lakes the impacts of WLFs as not as noticeable as in shallow lakes, extreme drawdown of lakes (e.g. more than $10 \mathrm{~m}$ ) can have a crucial effect on the thermal structure of the water column (Naselli-Flores and Barone, 2005). The excessive decrease of water level may change the thickness of the hypolimnion and might lead to enrichment of the epilimnion with hypolimnetic nutrients, causing rapid shifts in phytoplankton species composition (Naselli-Flores and Barone, 2005).

In Greece, many lakes have experienced progressive reduction in water level during the last few decades leading to several environmental perturbations (Naselli-Flores and Barone, 2005; Papastergiadou et al., 2010). The causes of this are not clearly understood and can be attributed to a number of different factors.

Intensive agricultural activity and rising needs of water supplies for domestic and industrial use are some of the main causes that can enhance eutrophication and amplify the effects of water level fluctuation (Crisman et al., 2005; Castillio et al., 2012). Undoubtedly, climate plays a vital role in controlling the hydrology of lakes as it determines both the inputs and outputs of water and the residence time. There is also an indirect impact of climate change on the hydrological balance of freshwaters, related to the increased need for water for agriculture. Water abstraction for irrigation consists of a common practice among the farmers, especially during the warm and dry summer that may enhance the water level drop.

Therefore there is a profound need to investigate both the causes and effects of these ongoing hydrological alterations in order to develop effective mitigation and restoration measures. The main objective of the current research is to evaluate the possible effects of a long term water level decline in some key biota and the water chemistry of an important lake of Greece. The studied lake has had extreme water loss in the last decades which offered us the opportunity to study the consequent responses of aquatic communities to this hydrological 

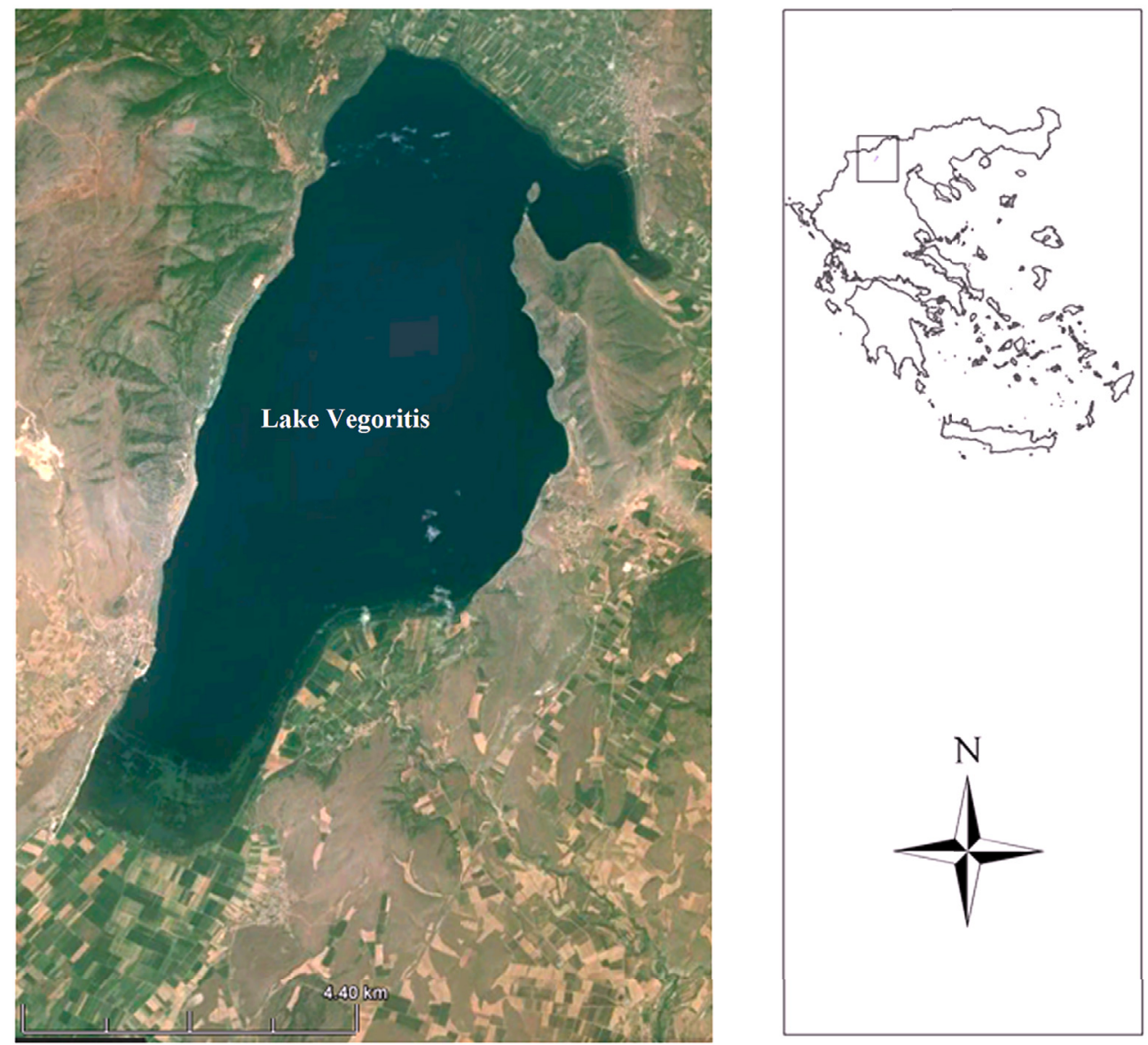

Figure 1

Location map of the studied lake Vegoritis in Northern Greece, and the outline of the lake.

disturbance. We assessed data from recent and past field surveys that describe the ecological status of the lake in different time periods and hence are representative of the water level during each period. We hypothesized that the extreme water level draw down would have a significant impact on the conductivity levels of the lake and would affect the structure of the fish community. We expected that because of the water level reduction the trophic status of the lake would shift towards more eutrophic limits resulting to a decline of aquatic macrophyte diversity and increase of zoobenthivorous fish. The results of this work provide useful conclusions regarding the effects of long term water level reduction on the biotic elements of Mediterranean lake ecosystems.

\section{MATERIALS AND METHODS}

\section{> STUDY AREA}

Lake Vegoritis is located in region of Macedonia, in northern Greece (Figure 1) and has been designated as a protected Natura 2000 site. The hydrological basin of the lake is surrounded by high mountains at the northern, eastern and western boundaries. At the southern part of the basin extends a large plain area where the majority of urban development and agricultural activities take place. Additionally, there is a heavy lignite mining activity taking place within the basin which constitutes a major environmental pressure. Within its boundaries there is a complex of four lakes which are hydrologically connected through wetland areas. Lake Vegoritis is the final receiving body of the surface runoff of the basin (Charou et al., 2010). It is also known 


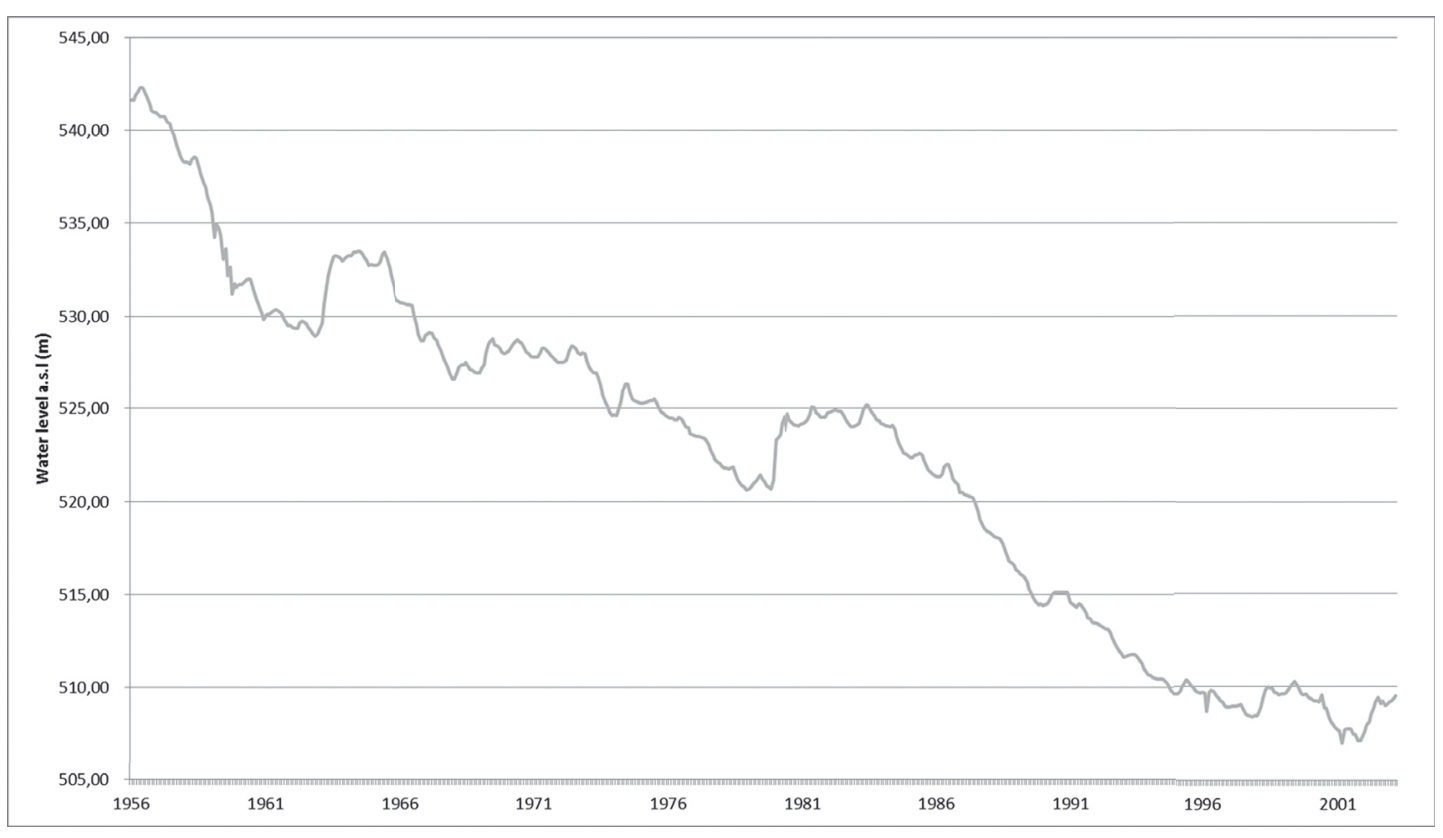

\section{Figure 2}

Monthly water level fluctuation from 1956 to 2001 of the studied lake Vegoritis.

that the southern part of the lake receives urban and agricultural wastewaters, as well as, erosion effluents and pollutants from the lignite mines (Skoulikidis et al., 2008). The lake is one of the largest water impoundments of Greece, with surface area of approximately $40 \mathrm{~km}^{2}$, mean depth $28.9 \mathrm{~m}$ and maximum depth around $40 \mathrm{~m}$. During the last five decades, the lake has been suffering from environmental pressures, such as agricultural and industrial driven pollution, and mostly by the huge decrease of water volume (water level decreased by $32 \mathrm{~m}$ since 1950s till 2002) in order to cover hydro-electrical demands from 1956 to 1985 (Skoulikidis et al., 2008). Due to this extreme water level decrease, from about $542 \mathrm{~m}$ a.s.l. in 1956 to $510 \mathrm{~m}$ a.s.I. today (Figure 2), the trophic state has been changed from oligotrophic at the beginning of 80 s to mesotrophic during the 90s (Gianniou and Antonopoulos, 2007).

\section{> FIELD SAMPLINGS}

Water samples for physicochemical and plankton analyses were collected from seven sampling sites during summer and autumn of 2006, spring, summer, and autumn of 2007, and spring and summer of 2008. Dissolved oxygen, pH, conductivity, temperature and Secchi depth were measured in situ using a portable YSI sensor and a Secchi disk. Nitrate, nitrite, ammonium, phosphate, total phosphorus, carbonate, bicarbonate and chlorophyll-a concentrations were determined following the analytical procedure of APHA (APHA, 1992). For the quantification of the zooplankton, subsamples were collected within the macrophyte beds using a tube and were pooled into a vessel in order to form an integrated sample of approximately 10 L (Kuczyńska-Kippen, 2003; Stefanidis and Papastergiadou, 2010). A volume of 6-7 $L$ was finally concentrated through a $50 \mu \mathrm{m}$ net and fixed immediately with Lugol's solution. Rotifera and Cladocera were counted using a Sedgewick-Rafter cell and were identified at species or genus level.

Aquatic macrophyte abundance was visually estimated according to a five point scale (1: rare, 2: common, 3: frequent, 4: abundant, 5: dominant, Stefanidis and Papastergiadou, 2010). Frequencies of occurrence were calculated for each taxon at the two different time periods and the taxa were classified into the following categories: rare $(<0.25 \%$ of quadrats), occasional 
( $0.26-1 \%$ of quadrats), common ( $1-5 \%$ of quadrats), abundant (5-20\% of quadrats) and very abundant ( $>20 \%$ of quadrats) (Papastergiadou et al., 2010).

\section{> LONG TERM DATA}

Monthly water level records for the period 1896-2001 were acquired from the Department of Environment, Region of Western Macedonia. Temporal data series of mean monthly conductivity and chloride concentration from 1983 until 2001 were obtained from the Ministry of Rural Development and Agriculture. Other background information regarding the trophic status of the lake was acquired from field samplings conducted in 1987 and 1988 (Papastergiadou and Babalonas, 1993) Past records of aquatic macrophyte abundance and composition were based on field surveys carried out during 1987 and 1988 (Papastergiadou and Babalonas, 1993).

In order to evaluate the changes in the fish community we used fisheries data that were assessed from the Hellenic Ministry of Rural Development and Food and were published through the PESCA database project (Paschos and Kagalou, 2000).

\section{> STATISTICAL ANALYSIS}

Mann-Whitney $U$ test was conducted to compare the mean ranks of water chemistry and fish data during two time periods of different water level. Additionally, non-parametric Pearson correlations were run between temporal water level, water chemistry and fish biomass from 1980 to 2000. Statistical analysis was performed with SPSS 19.

\section{RESULTS}

\section{> CHANGES OF AQUATIC MACROPHYTES}

Changes in aquatic vegetation were assessed by comparing the relative frequency of aquatic macrophytes (Table I) and qualitative observations of macrophyte distribution during one high water level (1987-1988) and one low water level (2006-2008) period. Additionally, a map of the lake (and the broader Natura 2000 protected area), that shows the extent of the aquatic vegetation and a rough illustration of the bathymetry, was drawn for each period based on digital imagery (Figure 3).

During 1987-1988 (high water level period), the aquatic vegetation was limited to the lake shores (Figure 3). The submerged hydrophytes Potamogeton perfoliatus and Vallisneria spiralis were the most common taxa at that period. Interestingly, the charophyte Chara vulgaris appears to have contributed significantly to the macrophyte composition of the lake during that period (Table I).

In contrast, according to our recent observations in 2006-2008 (low water level period), the helophytic vegetation appears to form extended reed beds in the southern part of the lake (Figure 3). Furthermore, the submerged macrophytes form a thicker zone along the shoreline of the lake which is mostly dominated by Vallisneria spiralis, Myriophyllum spicatum and Potamogeton pectinatus. However, a more diverse community is established in the southern part of the lake, among the reed beds, and is composed by several macrophytes such as $V$. spiralis, M. spicatum, Potamogeton pectinatus, $P$. perfoliatus, Ceratophyllum demersum, $P$. lucens, P. crispus, and Ranunculus trichophyllus (Table I). The relative frequencies of $M$. spicatum and $P$. pectinatus have increased, while $P$. perfoliatus appears to be less common. More importantly, Chara vulgaris has disappeared from the field samplings in 2006-2008 (Table I). 


\section{Table I}

Changes of water chemistry, hydrophytes and fish in lake Vegoritis during the investigated time periods with different water level. Significance value of Mann-Whitney test is given when applicable.

\begin{tabular}{|c|c|c|c|}
\hline Time period & $1987-1988$ & $2006-2008$ & Mann-Whitney U test Sig. \\
\hline Water level (m a.s.l) & 519.6 & $\approx 510$ & \\
\hline \multicolumn{4}{|l|}{ Water chemistry } \\
\hline Conductivity $\left(\mu \mathrm{S} \cdot \mathrm{cm}^{-1}\right)$ & $413.6 \pm 39.1$ & $677.2 \pm 113.2$ & 0.000 \\
\hline Dissolved inorganic nitrogen $\left(\mathrm{mg} \cdot \mathrm{L}^{-1}\right)$ & $1.19 \pm 0.47$ & $0.37 \pm 0.37$ & 0.000 \\
\hline Soluble reactive phosphorus $\left(\mu \mathrm{g} \cdot \mathrm{L}^{-1}\right)$ & $7.1 \pm 4.3$ & $17.3 \pm 37.8$ & 0.278 \\
\hline Chl-a $\left(\mu g \cdot L^{-1}\right)$ & - & 3 & $\mathrm{n} / \mathrm{a}$ \\
\hline \multicolumn{4}{|l|}{ Hydrophytes (relative frequency) } \\
\hline Ceratophyllum demersum L. & 0.14 & 0.16 & $\mathrm{n} / \mathrm{a}$ \\
\hline Chara vulgaris L. & 0.33 & 0 & $\mathrm{n} / \mathrm{a}$ \\
\hline Myriophyllum spicatum L. & 0.52 & 0.67 & $\mathrm{n} / \mathrm{a}$ \\
\hline Najas marina L. & 0.24 & 0.23 & $\mathrm{n} / \mathrm{a}$ \\
\hline Najas minor L. & 0.04 & 0 & $\mathrm{n} / \mathrm{a}$ \\
\hline Potamogeton crispus L. & 0 & 0.02 & $\mathrm{n} / \mathrm{a}$ \\
\hline Potamogeton Iucens L. & 0 & 0.02 & $\mathrm{n} / \mathrm{a}$ \\
\hline Potamogeton pectinatus L. & 0.38 & 0.59 & $\mathrm{n} / \mathrm{a}$ \\
\hline Potamogeton perfoliatus L. & 0.86 & 0.41 & $\mathrm{n} / \mathrm{a}$ \\
\hline Ranunculus trichophyllus Chaix. & 0 & 0.02 & $\mathrm{n} / \mathrm{a}$ \\
\hline Vallisneria spiralis L. & 0.90 & 0.78 & $\mathrm{n} / \mathrm{a}$ \\
\hline
\end{tabular}

\begin{tabular}{|l|c|c|c|}
\hline Time period & $1973-1979$ & $1990-1999$ & \\
\hline Water level (m a.s.I) & 523.8 & 511.6 & \\
\hline Fish (biomass \%) & \multicolumn{2}{|l|}{} \\
\hline Barbus cyclolepis Heckel & $1.82 \pm 1.66$ & $0.04 \pm 0.12$ & $\mathbf{0 . 0 0 5}$ \\
\hline Coregonus lavaretus L. & $23.36 \pm 6.4$ & $3.71 \pm 6.9$ & $\mathbf{0 . 0 0 1}$ \\
\hline Cyprinus carpio L. & $7.15 \pm 2.2$ & $33.2 \pm 27.1$ & 0.364 \\
\hline young carps & $20.95 \pm 5.01$ & $23.44 \pm 5.02$ & 0.648 \\
\hline Esox lucius L. & $0.26 \pm 0.34$ & $1.65 \pm 2.2$ & 0.669 \\
\hline Rutilus rutilus L. & $9.83 \pm 4.29$ & $40.7 \pm 15.4$ & $\mathbf{0 . 0 0 0}$ \\
\hline Scardinius erythropthalmus L. & $36.5 \pm 15.3$ & $12.6 \pm 10.97$ & $\mathbf{0 . 0 1 4}$ \\
\hline Silurus glanis L. & $0.09 \pm 0.12$ & $0.62 \pm 0.79$ & $\mathbf{0 . 0 2 5}$ \\
\hline Tinca tinca L. & 0 & $0.24 \pm 0.31$ & 0.056 \\
\hline
\end{tabular}

\section{$>$ ZOOPLANKTON}

The zooplankton samples of lake Vegoritis were composed of twenty two taxa of Rotifera and eleven taxa of Cladocera. Regarding the Rotifera, Polyarthra sp., Keratella cochlearis, and Trichocerca sp. are the most abundant taxa (Table II). Among Cladocera the most abundant species were the following: Chydorus sphaericus, Bosmina longirostris, and Diaphanosoma brachyurum. Cladocerans were mainly dominated by small-bodied species, therefore largesized daphnids contributed only in negligible percentages, being almost absent in our samples.

\section{> CHANGES IN FISH COMMUNITIES}

The fish composition differed significantly between the two time periods (Table I). Roach biomass (Rutilus rutilus) was significantly higher during the low water level period (1990-1999, 

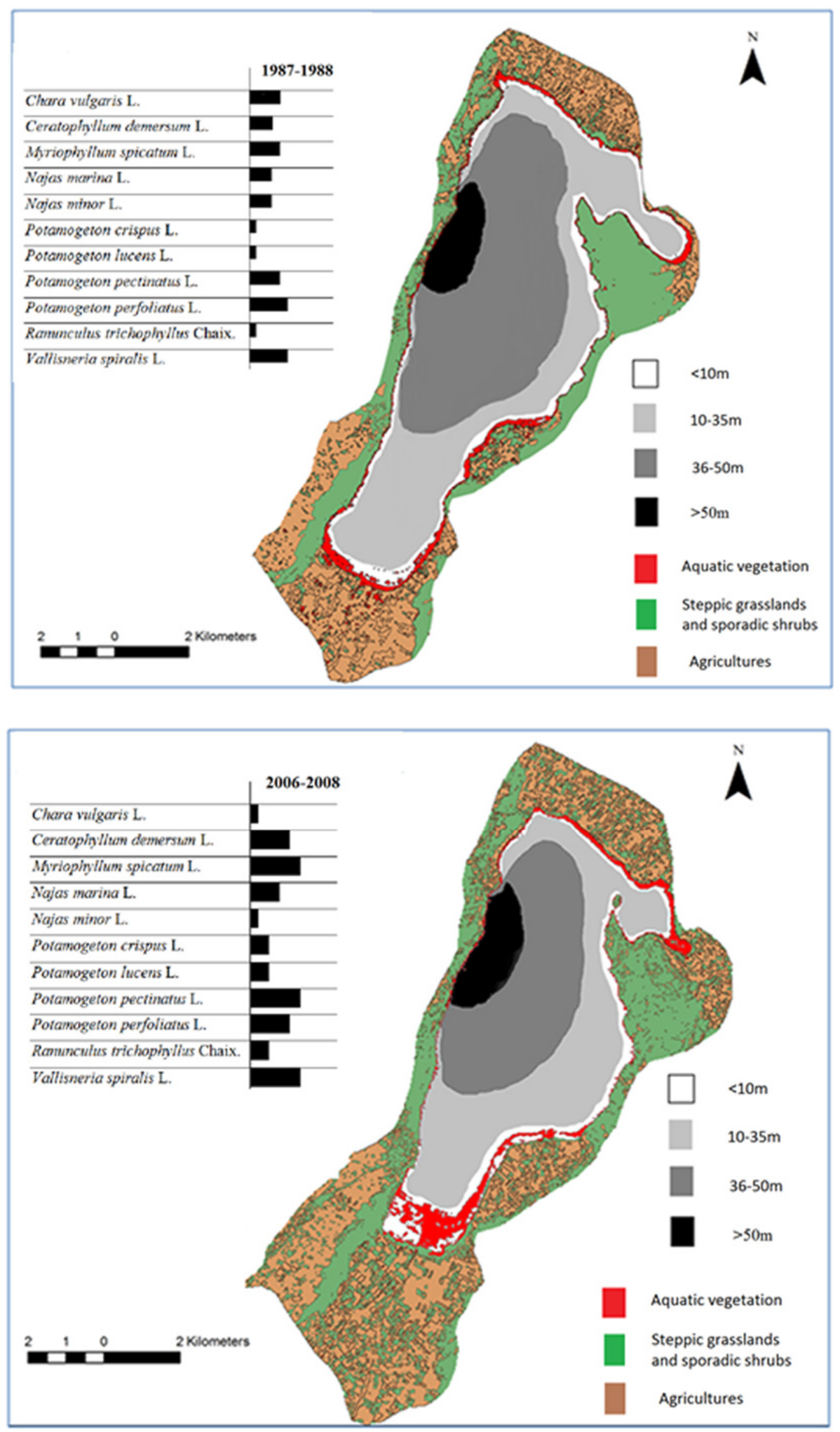

\section{Figure 3}

A schematic illustration of the protected area of lake Vegoritis and the cover of aquatic vegetation during two time periods. Bars representing the relative frequency of the hydrophyte species for each time period. 
Table II

Proportional abundance of Cladocera and Rotifera taxa recorded in lake Vegoritis during the 2006-2008 survey (the abundance of the taxa marked with * are included in their respective genera abundance).

\begin{tabular}{|c|c|}
\hline CLADOCERA & \\
\hline Alona rectangula G.O Sars & 2.3 \\
\hline Bosmina coregoni Baird & 0.2 \\
\hline Bosmina longirostris O. F. Müller & 5.6 \\
\hline Ceriodaphnia sp. & 3.6 \\
\hline Chydoridae & 0.1 \\
\hline Chydorus sphaericus O. F. Müller & 6.1 \\
\hline Daphnia sp. & 0.3 \\
\hline Diaphanosoma brachyurum Lievin & 4.2 \\
\hline Macrothrix sp. & 0.2 \\
\hline Moina micrura Kurz & 0.3 \\
\hline Simocephalus sp. & 0.2 \\
\hline \multicolumn{2}{|l|}{ COPEPODA } \\
\hline adults & 13.7 \\
\hline nauplii & 30.3 \\
\hline \multicolumn{2}{|l|}{ ROTIFERA } \\
\hline Anuraeopsis fissa Gosse & 0.5 \\
\hline Asplanchna sp. & 0.1 \\
\hline Brachionus angularis Gosse & 0.3 \\
\hline Brachionus calyciflorus Pallas & 1.7 \\
\hline Euchlanis dilatata Ehrenberg & 1.5 \\
\hline Filinia Iongiseta Ehrenberg & 0.2 \\
\hline Hexarthra mira Hudson & 0.4 \\
\hline Keratella cochlearis Gosse & 6.3 \\
\hline Keratella quadrata O. F. Müller & 0.5 \\
\hline Lecane bulla Gosse* & - \\
\hline Lecane luna O. F. Müller* & - \\
\hline Lecane lunaris Ehrenberg* & - \\
\hline Lecane spp. & 5.3 \\
\hline Lepadella spp. & 0.4 \\
\hline Notholca squamula O. F. Müller & 0.2 \\
\hline Polyarthra sp. & 11.3 \\
\hline Trichocerca pusilla Lauterborn* & - \\
\hline Trichocerca rattus O. F. Müller* & - \\
\hline Trıchocerca similis Wierzejski* & - \\
\hline Trichocerca weberi Jennings* & - \\
\hline Trichocerca spp. & 4.6 \\
\hline Trichotria sp. & 0.3 \\
\hline
\end{tabular}

Mann Whitney $U$ test sig. $<0.001$ ). Carp (Cyprinus carpio) biomass was also higher during the same period without however this difference being statistically significant (Table I). By contrast, whitefish (Coregonus lavaretus) and rudd (Scardinius erythropthalmus) biomass were significantly higher during the high water level period (1973-1979, Mann Whitney U test sig. $<0.05)($ Table I).

Pearson correlations revealed statistically significant relationships between the water level and the biomass of carps, roach, rudd and whitefish (Figure 4). Most notably, the biomass of whitefish was positively correlated with the water level $\left(r^{2}=0.706, p<0.001\right.$, Figure 4). The biomass of carp also showed a clear trend, being higher in years with low water level $\left(r^{2}=\right.$ $0.498, p<0.001$, Figure 4). The biomass of rudd and roach respectively showed significant positive $\left(r^{2}=0.18, p<0.05\right)$ and negative $\left(r^{2}=0.215, p<0.01\right)$ correlation with the water level. 

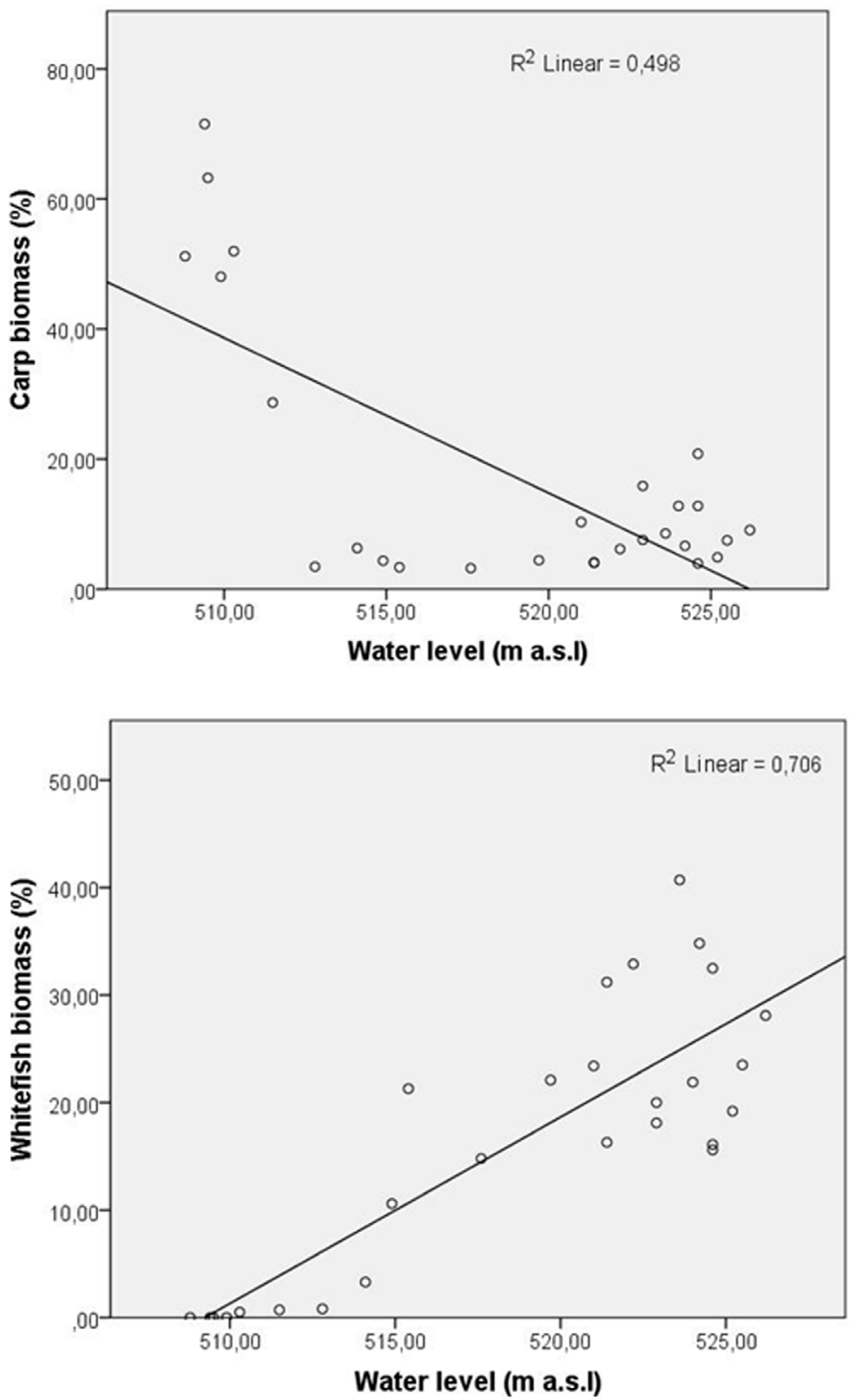

Figure 4

Scatter plots showing the relationships between mean annual water level and annual proportional biomass of carp and whitefish from 1973 to 1999 in lake Vegoritis.

\section{> WATER CHEMISTRY}

Table III presents mean values for water chemistry variables measured among the seven sampling sites during the 2006-2008 survey. Soluble reactive phosphorus ranged from 9.3 to $49.8 \mu \mathrm{g} \cdot \mathrm{L}^{-1}$, dissolved inorganic nitrogen varied from 237 to $537 \mu \mathrm{g} \cdot \mathrm{L}^{-1}$ and chlorophyll-a, fluctuated from 2 to $5.1 \mu \mathrm{g} \cdot \mathrm{L}^{-1}$ reflecting a rather mesotrophic state. The results of Mann-Whitney $U$ test revealed statistically significant differences $(p<0.001)$ between the two time periods (1987-1988 and 2006-2008) for the concentration of DIN and the conductivity (Table I). Specifically, mean conductivity increased from 413.6 to $677.2 \mu \mathrm{S} \cdot \mathrm{cm}^{-1}$, while the mean concentration of DIN decreased from 1.19 to $0.37 \mathrm{mg} \cdot \mathrm{L}^{-1}$.

Further analysis of the long term data revealed that from 1983 to 2001 the mean annual lake conductivity and chloride concentration increased continuously from $495 \mu \mathrm{S} \cdot \mathrm{cm}^{-1}$ and 


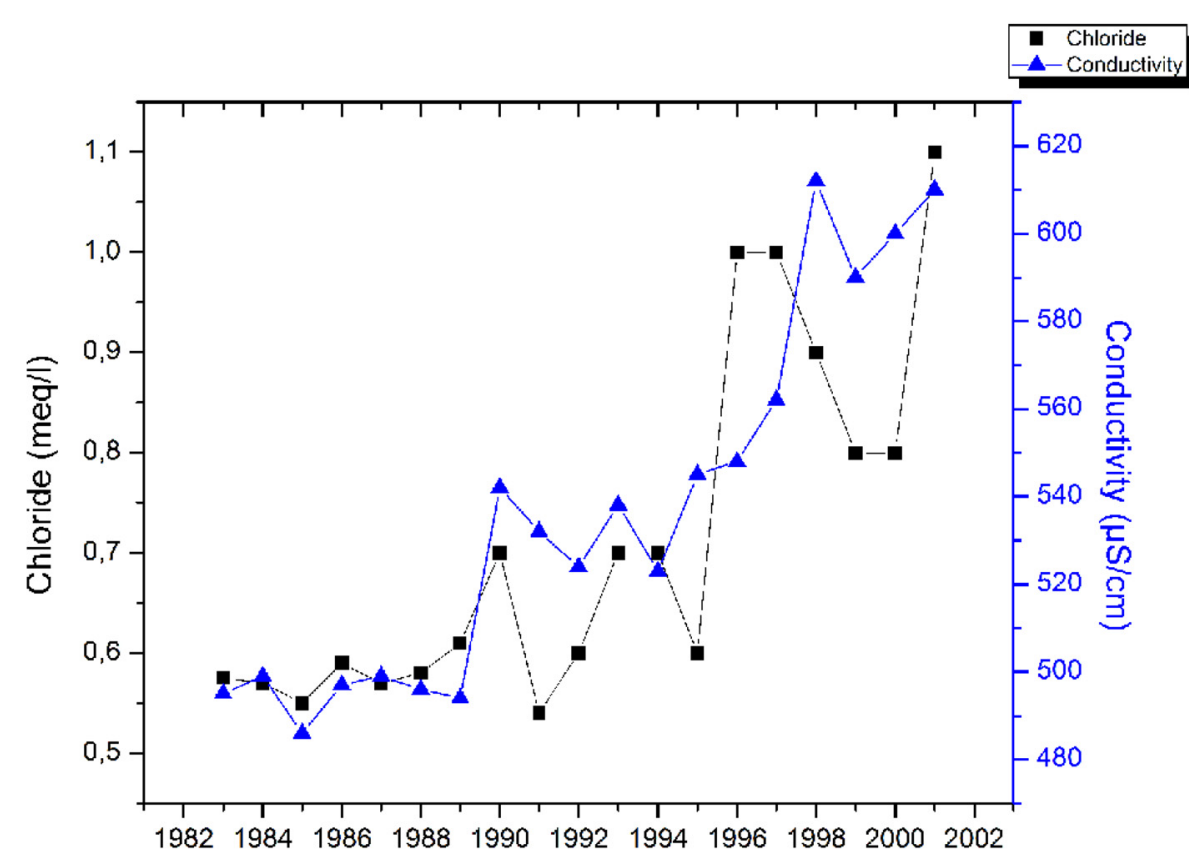

Figure 5

Temporal changes of conductivity and chloride concentration from 1983 to 2001 in lake Vegoritis.

\section{Table III}

Mean values of key abiotic variables measured during 2006-2008 (standard error in brackets).

\begin{tabular}{|l|c|c|c|c|c|}
\hline Site No & SRP $\left(\mu \mathrm{g} \cdot \mathrm{L}^{-1}\right)$ & DIN $\left(\mu \mathrm{g} \cdot \mathrm{L}^{-1}\right)$ & $\mathrm{Chl}^{-a}\left(\mu \mathrm{g} \cdot \mathrm{L}^{-1}\right)$ & $\mathrm{pH}$ & Depth $(\mathrm{m})$ \\
\hline $\mathbf{1}$ & $16.0(7.3)$ & $303(138)$ & $4.5(1.0)$ & $8.05(0.2)$ & 1 \\
\hline $\mathbf{2}$ & $9.3(3.1)$ & $237(123)$ & $2.9(0.6)$ & $8.15(0.2)$ & 1 \\
\hline $\mathbf{3}$ & $14.4(4.7)$ & $537(154)$ & $5.1(1.3)$ & $8.13(0.2)$ & 1.2 \\
\hline $\mathbf{4}$ & $10.2(3.9)$ & $437(146)$ & $3.9(1.3)$ & $7.95(0.2)$ & 1 \\
\hline $\mathbf{5}$ & $12.8(3.4)$ & $376(128)$ & $2.2(0.8)$ & $7.95(0.2)$ & 1 \\
\hline $\mathbf{6}$ & $17.1(7.0)$ & $307(90)$ & $2.2(0.7)$ & $8.14(0.1)$ & 1.2 \\
\hline $\mathbf{7}$ & $49.8(44.3)$ & $429(185)$ & $2.0(0.7)$ & $8.04(0.3)$ & 4 \\
\hline
\end{tabular}

$0.58 \mathrm{meq} \cdot \mathrm{L}^{-1}$ to $610 \mu \mathrm{S} \cdot \mathrm{cm}^{-1}$ and $1.1 \mathrm{meq} \cdot \mathrm{L}^{-1}$ respectively (Figure 5). These trends in conductivity and chloride were strongly correlated $\left(r^{2}=0.734\right.$ and $r^{2}=0.551$, sig. $\left.<0.001\right)$ with the water level, suggesting a possible strong effect on the water chemistry (Figure 6).

\section{DISCUSSION}

Our research indicated that an extreme water level reduction can have a profound effect on the ecology of a deep lake. The water chemistry, aquatic vegetation and fish community of the studied lake have been significantly altered during the last decades. These changes occurred mostly after 1970's and coincided with a simultaneous water level decrease by almost $30 \mathrm{~m}$. According to the results of this research the water chemistry of the lake (SRP, DIN, Chl-a) is ranked now into a rather mesotrophic towards eutrophic profile. What is more interesting is that there is clear evidence that a gradual increase of conductivity and chloride concentration took place during the last decades that correlates with the lake water level. These results support the hypothesis that hydrological regime alterations are expected to play a significant role in determining water quality, and in particular may enhance the salinity levels in freshwater ecosystems of arid and semi-arid areas of the world (Nielsen and Brock, 2009). However, it is not unlikely that the rise of chloride and conductivity levels may be indirectly connected 

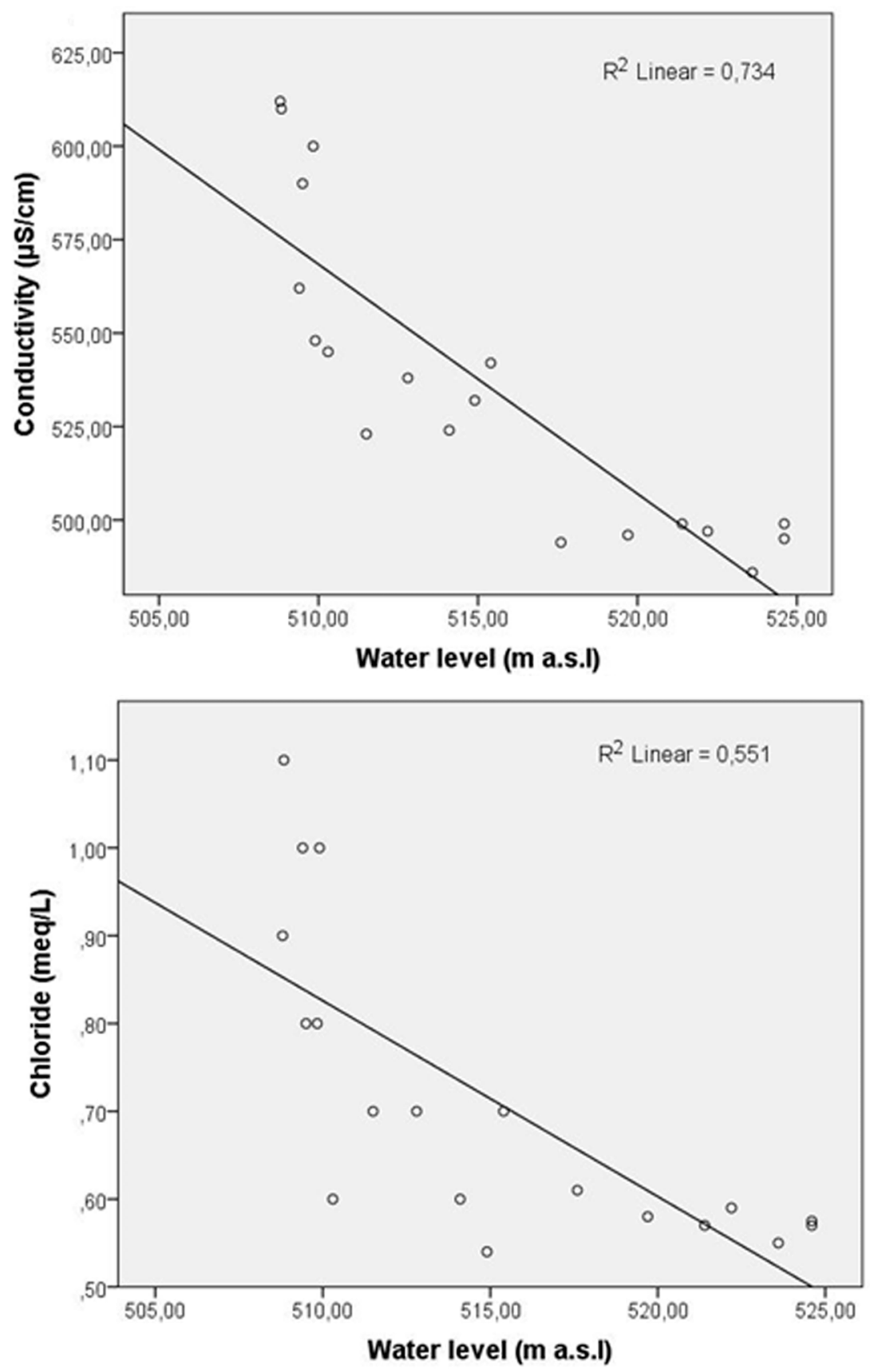

Figure 6

Scatter plots showing the relationships between mean annual water level and mean annual conductivity and chloride from 1983 to 2001 in lake Vegoritis.

to the increase of adjacent agricultural cultivations and subsequent irrigation works. Specifically, irrigation based on underground water and usually containing salt, suspended solids and other elements, may possibly impact the water bodies. This process involves the leaching and drainage that is required to maintain the productivity of crops and transfers salts and other constituents from soils into rivers and lakes affecting the water chemistry (Wichelns and Osters, 2006).

The recorded shifts of the aquatic vegetation appear to further support the indication that a significant change in water quality of the lake has taken place. The charophyte Chara vulgaris was absent from the 2006-2008 samplings, whereas the frequency of the angiosperm 
P. pectinatus has almost doubled during the same period. The Charophytes are often regarded as indicators of clear water ecosystems, and replacement by angiosperms, such as Potamogeton pectinatus, is a sign of nutrient pollution and eutrophication (Körner, 2002; Kłosowski et al., 2006). The cosmopolitan angiosperm $P$. pectinatus in particular can occur in a wide range of salinities, from freshwater to seawater, but it appears to be better adapted in conditions of low light intensity, high nutrient content and oligohaline salinity (Prado et al., 2013; Manolaki and Papastergiadou, 2013). In the current research, this is an important finding as it denotes an indirect effect of the water level reduction on the macrophyte composition.

The water level reduction had also a clear impact on the extent of the aquatic vegetation of the studied lake. More specifically, in the southern part of the lake the reed beds have expanded, due to the water level drop, covering a significant area of the lake surface. This study has also revealed that due to the water level decline, the development of submerged vegetation is now possible at the shallower part of the lake, despite the high concentrations of phosphorus and nitrogen. These results are consistent with those of other studies and suggest that the inter-annual or seasonal changes in water level are crucial for macrophyte growth especially in the Mediterranean lakes (Coops et al., 2003; Beklioglu et al., 2006). The pattern of these water level alterations is important for the determination of the littoral zone and the aquatic macrophyte communities (Coops et al., 2003; Krolová et al., 2013). Low water level may often enhance the biomass and coverage of aquatic macrophytes, depending on the lake morphometry and bathymetry (Beklioglu et al., 2006). Even when nutrient levels are high and fish induced top down control is intense, a water level reduction may maintain the growth of aquatic macrophytes at least in the Mediterranean shallow lakes (Bucak et al., 2012).

One of the key findings of this research is the significant increase of zoobenthivorous roach $(p<0.001)$ in relation to the water level decline that underlines the enhancement of eutrophication processes (Lammens, 1999; Voutilainen and Huuskonen, 2010). In addition, it was shown that the proportional biomass of carp was significantly correlated with the water level decrease over a period of almost thirty years. On the other hand, the Coregonus lavaretus population of the lake presented a strong negative correlation with the water level $\left(r^{2}=0.706\right.$, $p<0.001$ ) suggesting a clear effect of the hydrological alteration on the fish community. This pattern of changes with a shift from salmonids to cyprinids is often attributed to increase of eutrophication in several European lakes (Jeppesen et al., 2000). In our case these results support the hypothesis that the water level reduction has indirectly affected the structure of the fish composition through changes in water quality and possibly in aquatic vegetation. For example, the recorded decline of rudd (Scardinius erythrophthalmus) could be a sign of the loss of the diversity of submersed macrophyte species that serve as a reproduction and foraging habitat (Lake et al., 2002). In addition, the results regarding the zooplankton species composition seem to agree with the observed changes in the fish composition. Only few large sized Cladocera taxa were recorded while the smaller sized taxa, like Bosmina spp., were found in large numbers. The absence of large Cladocera grazers is often interpreted as an indication of fish predation pressure (Jeppesen et al., 1999) and in this case is probably related to the increase of the zoobenthivorous fish in the lake (roach) since the 1980s. The cyprinids, such as roach (Rutilus rutilus), are well known to disturb the lake bottom and feed on large zooplankton (Lammens, 1999), enhancing thus the eutrophication and turbidity effects in lakes. On the other hand, the small sized Cladocerans, such as Bosmina spp., are less affected by fish predation and so they are able to maintain their numbers (St. Jacques et al., 2005). This appears to be the case in our study since the cladocerans were dominated by small sized Bosmina spp along with Chydorus sphaericus, although the high abundance of Chydorus sphaericus is related to the dense submerged vegetation (Mastrantuono and Mancinelli, 2005; Walseng et al., 2006) where the samplings were mostly conducted. Most of the recorded taxa (Keratella quadrata, Keratella cochlearis, Trichocerca sp, Filinia longiseta, Brachionus sp, Bosmina longirostris) are quite common and abundant in several eutrophic freshwaters of Greece (Michaloudi et al., 1997; Kagalou and Leonardos, 2009; Stefanidis and Papastergiadou, 2010). Overall, the zooplankton of the lake Vegoritis is dominated 
mostly by nauplii, followed by rotifers and small sized crustaceans. This pattern of zooplankton composition appears to be dominant in the majority of Greek lakes and is attributed to the eutrophic conditions and increased fish predation (Kagalou and Leonardos, 2009).

Our key results underline the fact that lake Vegoritis exhibited some alarming signs of ecological degradation. Taken together, the low abundance of large zooplankton, the shift of fish towards zoobenthivorous cyprinids and the loss of charophytes underline the effects of the agriculture driven eutrophication on the aquatic communities. Furthermore, our results support the hypothesis that long term hydrological alterations eventually may have a significant impact both on the water chemistry and the ecology of the lake. The long term water level fluctuations influence the ecosystems dynamic and pose an important threat to the aquatic communities of the freshwater ecosystems. Therefore an effective restoration plan should target both the reduction of nutrient loading and water level management in compliance with the European and national environmental policies, in order to achieve an improvement of the trophic and ecological status.

\section{ACKNOWLEDGEMENTS}

This research was funded by grants from State Scholarships Foundation Research of the Greek Ministry of Education and was supported by the EU FP7 project REFRESH (Adaptive strategies to mitigate the impacts of Climate Change on European Freshwater Ecosystems). We wish to thank Dr. Natalia Kuczyńska-Kippen, (University of Adam Mickiewicz, Poland) for her invaluable guidance and counsel on assessing and identifying zooplankton samples, as well as Anna Basińska and Kasper Świdnicki for their valuable advice on the identification of zooplankton species. We greatly appreciate Dr Vasiliki Rizomilioti, EAP Tutor of Patras University, and Dr Panagiotis Kotsantis from University of Birmingham for the linguistic revision of the manuscript.

Finally, we are grateful to the Editor Daniel Gerdeaux and to the anonymous reviewers for the careful revision and valuable critical comments on the manuscript.

\section{REFERENCES}

American Public Health Association (APHA), 1992. Standard methods for the examination of water and wastewater, 18th Edition. American Public Health Association, Washington, D.C.

Beklioglu M., Altinayar G. and Tan C.O., 2006. Water level control over submerged macrophyte development in five shallow lakes of Mediterranean Turkey. Arch Hydrobiol, 166, 535-556.

Bucak T., Saraoğlu E., Levi E., Tavşanoğlu N., Çakiroğlu A.I.,, Jeppesen E. and Beklioğlu M., 2012. The influence of water level on macrophyte growth and trophic interactions in eutrophic Mediterranean shallow lakes: A mesocosm experiment with and without fish. Freshwater Biol., 57, 1631-1642.

Castillio M.M., Morales H., Valencia E., Morales J.J. and Cruz-Motta J.J., 2012. The effects of human land use on flow regime and water chemistry of headwater streams in the highlands of Chiapas. Knowl. Managt. Aquatic Ecosyst., 407, 09.

Charou E., Stefouli M., Dimitrakopoulos D., Vasiliou E. and Mavrantza O.D., 2010. Using remote sensing to assess impact of mining activities on land and water resources. Mine Water Environ., 29, 45-52.

Coops H., Beklioglu M. and Crisman T.L., 2003. The role of water-level fluctuations in shallow lake ecosystems - workshop conlusions. Hydrobiologia, 506-509, $23-27$.

Crisman T.L., Mitraki C. and Zalidis G., 2005. Integrating vertical and horizontal approaches for management of shallow lakes and wetlands. Ecol. Eng., 24, 379-389.

Gianniou S.K. and Antonopoulos V., 2007. Evaporation and energy budget in Lake Vegoritis, Greece. J. Hydrol., 345, 212-223.

Jeppesen E., Jensen J.P., Søndergaard M. and Lauridsen T., 1999. Trophic dynamics in turbid and clear water lakes with special emphasis on the role of zooplankton for water clarity. Hydrobiologia, 408-409, 217-231. 
Jeppesen E., Jensen J.P., Søndergaard M., Lauridsen T. and Landkildehus F., 2000. Trophic structure, species richness and biodiversity in Danish lakes: changes along a phosphorus gradient. Freshwater Biol., 45, 201-218.

Kagalou I. and Leonardos I., 2009. Typology, classification and management issues of Greek lakes: implication of the Water Framework Directive (2000/60/EC). Environ. Monit. Assess., 50, 469-484.

Kłosowski S., Tomaszevicz G.H. and Tomaszevicz H., 2006. The expansion and decline of charophyte communities in lakes within the Sejny Lake District (north-eastern Poland) and changes in water chemistry. Limnologica, 36, 234-240.

Körner S., 2002. Loss of submerged macrophytes in shallow lakes in north-eastern Germany. Int. Rev. Hydrobiol., 87, 375-384.

Krolová M., Č́žzova H., Hejzlar J. and Poláková S., 2013. Response of littoral macrophytes to water level fluctuations in a storage reservoir. Knowl. Managt. Aquatic Ecosyst., 408, 07.

Kuczyńska-Kippen N., 2003. The distribution of rotifers (Rotifera) within a single Myriophyllum bed. Hydrobiologia, 506-509, 327-331.

Lake M.D., Hicks B.J., Wells R.D.S. and Dugdale T.M., 2002. Consumption of submerged aquatic macrophytes by rudd (Scardinius erythrophthalmus L.) in New Zealand. Hydrobiologia, 47, 13-22.

Lammens E.H.R.R., 1999. The central role of fish in lake restoration and management. Hydrobiologia, 395-396, 191-198.

Manolaki P. and Papastergiadou E., 2013. The impact of environmental factors on the distribution pattern of aquatic macrophytes in a middle-sized Mediterranean stream. Aquat. Bot., 104, 34-46.

Mastrantuono L. and Mancinelli T., 2005. Littoral invertebrates associated with aquatic plants and bio assessment of ecological status in Lake Bracciano (Central Italy). J. Limnol., 64, 43-53.

Michaloudi E., Zarfdjian M. and Economidis P.S., 1997. The zooplankton of lake Mikri Prespa. Hydrobiologia, 351, 77-94.

Naselli-Flores L. and Barone R., 2005. Water-level fluctuations in Mediterranean reservoirs: Setting a dewatering threshold as a management tool to improve water quality. Hydrobiologia, 548, 85-99.

Nielsen D.L. and Brock M.A., 2009. Modified water regime and salinity as a consequence of climate change: prospects for wetlands of Southern Australia. Climatic Change, 95, 523-533.

Papastergiadou E. and Babalonas D., 1993. The Relationships between Hydrochemical Environmental factors and the Aquatic Macrophytic Vegetation in Stagnant and Slow Flowing Waters II. Evaluation of Plant Associations Indicative Value. Arch. Hydrobiol., 90, 493-506.

Papastergiadou E., Kagalou I., Stefanidis K., Retalis A. and Leonardos I., 2010. Effects of Anthropogenic Influences on the Trophic State, Land Uses and Aquatic Vegetation in a Shallow Mediterranean Lake: Implications for Restoration. Water Resour. Manag., 24, 415-435.

Paschos I. and Kagalou I., 2000. PESCA Project, Final Report, Ministry of Agriculture, Igoumenitsa, Greece.

Prado P., Caiola N. and Ibáñez C., 2013. Spatio-Temporal patterns of submerged macrophytes in three hydrologically altered Mediterranean coastal lagoons. Estuaries Coasts, 36, 414-429.

Romo S., Miracle M.R., Villena M.-J., Rueda J., Ferriol C. and Vicente E., 2004. Mesocosm experiments on nutrient and fish effects on shallow lake food webs in a Mediterranean climate. Freshwater Biol., 49, 1593-1607.

Skoulikidis N., Kaberi H. and Sakellariou D., 2008. Patterns, origin, and possible effects of sediment pollution in a Mediterranean lake. Hydrobiologia, 613, 71-83.

St Jacques J., Douglas M.S.V., Price N., Drakulic N. and Gubala C.P., 2005. The effect of fish introductions on the diatom and cladoceran communities of Lake Opeongo, Ontario, Canada. Hydrobiologia, 549, 99-113.

Stefanidis K. and Papastergiadou E., 2010. Influence of hydrophyte abundance on the spatial distribution of zooplankton in selected lakes in Greece. Hydrobiologia, 656, 55-65.

Voutilainen A. and Huuskonen $\mathrm{H}$., 2010. Long-term changes in the water quality and fish community of a large boreal lake affected by rising water temperatures and nutrient-rich sewage discharges with special emphasis on the European perch. Knowl. Managt. Aquatic Ecosyst., 397, 03.

Walseng B., Hessen D.O., Halvorsen G. and Schartau A.K., 2006. Major contribution from littoral crustaceans to zooplankton species richness in lakes. Limnol. Oceanogr., 51, 2600-2616.

Wichelns D. and Oster J.D., 2006. Sustainable irrigation is necessary and achievable, but direct costs and environmental impacts can be substantial. Agr. Water Manage., 86, 114-127. 